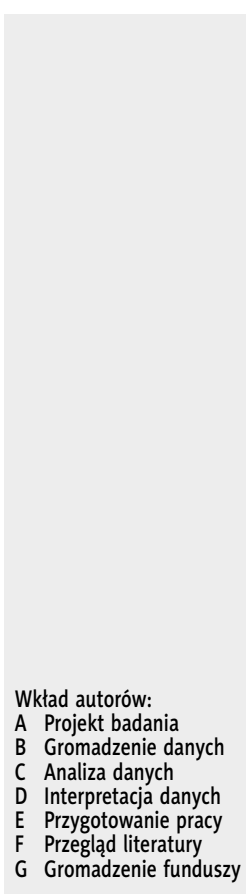

\title{
Analiza map potrzeb zdrowotnych w zakresie chorób zatok przynosowych w Polsce
}

\section{The analysis of maps of healthcare needs in the field of chronic rhinosinusitis in Poland}

\author{
Piotr H. Skarżyński ${ }^{1,3,4,5 E}$, Sandra Wawszczyk ${ }^{1 \mathrm{CDEF}}$, \\ Aleksandra Dąbkowska ${ }^{1 \mathrm{CDEF}}$, Bartosz Stawowski ${ }^{2 \mathrm{BCE}}$, \\ Elżbieta Włodarczyk ${ }^{1 \mathrm{E}}$, Henryk Skarżyński ${ }^{1 \mathrm{E}}$
}

\footnotetext{
${ }^{1}$ Instytut Fizjologii i Patologii Słuchu, Światowe Centrum Słuchu, Kajetany/Warszawa

${ }^{2}$ Departament Analiz i Strategii, Ministerstwo Zdrowia, Warszawa

${ }^{3}$ Warszawski Uniwersytet Medyczny, II Wydział Lekarski, Zakład Niewydolności Serca i Rehabilitacji Kardiologicznej, Warszawa

${ }^{4}$ Instytut Fizjologii i Patologii Słuchu, Światowe Centrum Słuchu, Zakład Teleaudiologii i Badań Przesiewowych, Kajetany/Warszawa

${ }^{5}$ Instytut Narządów Zmysłów, Kajetany
}

\section{Streszczenie}

Wstęp: Przewlekłe zapalenie zatok przynosowych (PZZP) jest nie tylko uważane za jedną z najczęstszych chorób przewlekłych w krajach rozwiniętych, lecz także ma istotny negatywny wpływ na jakość życia pacjentów, codzienną pracę, oraz na zwiększenie wydatków na opiekę zdrowotną, w tym w dużej mierze na hospitalizacje. W terapii PZZP stosuje się leczenie farmakologiczne oraz operacyjne z coraz powszechniejszym wykorzystaniem endoskopowej chirurgii zatok (ESS).

Cel: Celem pracy była analiza map potrzeb zdrowotnych (MPZ) w zakresie chorób zatok przynosowych w Polsce oraz przegląd najnowszych doniesień ze świata dotyczących leczenia PZZP. Choroby nosa i zatok przynosowych są najczęściej występującym schorzeniem wśród chorób z zakresu otorynolaryngologii, dlatego analiza odnośnych map potrzeb zdrowotnych jest istotna i ma swoje uzasadnienie. Materiały i metody: Przeanalizowano mapy potrzeb zdrowotnych - opublikowane przez Ministerstwo Zdrowia - dotyczące chorób zatok przynosowych ze wszystkich województw w zakresie lecznictwa szpitalnego za rok 2014 oraz dostępną literaturę na temat leczenia PZZP w latach 2012-2018 w wyszukiwarce PubMed.

Wyniki: W Polsce w 2014 roku współczynnik zapadalności na choroby nosa, zatok przynosowych, ucha, gardła i krtani wynosił 5762,8 na 100 tys. ludności, a współczynnik chorobowości - 41 258,7 na 100 tys. Odnotowano 5,132 mln porad ambulatoryjnych z powodu powyższych schorzeń, z czego $47,5 \%$ to porady pacjentów, którzy pojawili się co najmniej trzy razy. Z przyczyn otorynolaryngologicznych zarejestrowano 288,4 tys. hospitalizacji.

Wnioski: MPZ są narzędziem wspomagającym podejmowanie decyzji o charakterze systemowym, jak i działań prowadzonych w odniesieniu do poszczególnych uczestników systemu ochrony zdrowia.

Słowa kluczowe: przewlekłe zapalenie zatok przynosowych $\bullet$ PZZP • mapy potrzeb zdrowotnych

\begin{abstract}
Adres autora: Piotr H. Skarżyński, Światowe Centrum Słuchu, Instytut Fizjologii i Patologii Słuchu, ul. Mokra 17, 05-830 Nadarzyn, e-mail: p.skarzynski@ifps.org.pl
\end{abstract}

Introduction: Chronic rhinosinusitis (CRS) is considered to be one of the most common chronic diseases in developed countries, but also has a significant negative impact on the quality of life of patients, daily work and expenses on healthcare, including hospitalization. In CRS therapy, pharmacological and surgical treatment are used with an increasing role of endoscopic sinus surgery (ESS). Aim: The aim of the study was to analyze the maps of healthcare needs in the field of CRS in Poland and to review the latest reports regarding CRS treatment. Diseases of the nose and paranasal sinuses are the most common disorders among diseases in the field of otorhinolaryngology, therefore the analysis of the map of healthcare needs in this area is important and had its justification. 
Materials and methods: We analyzed the maps of healthcare needs from all voivodeships in 2014 regarding CRS, which were published by the Polish Ministry of Health. We also conducted an electronic literature search using the PubMed database to detect the newest articles about the treatment of CRS published between 2012 and 2018.

Results: The incidence rate of the diseases of the nose, paranasal sinuses, ear, throat and larynx in 2014 in Poland was 5762.8 cases per 100000 , and the prevalence rate - 41258.7 cases per 100 000. There were 5132000 outpatient consultations reported and $47.5 \%$ of them were visits of patients who visited the doctor at least 3 times. There were 288400 hospitalizations registered at Ear, Nose and Throat Departments.

Conclusions: The maps of healthcare needs is a tool which supports systemic decision-making as well as actions taken in relation to individual participants of the healthcare system.

Keywords: chronic rhinosinusitis $\bullet$ CRS $\bullet$ maps of healthcare needs

\begin{tabular}{|c|c|}
\hline Skrót & Rozwinięcie skrótu \\
\hline CRS & przewlekłe zapalenie zatok przynosowych \\
\hline CRSsNP & $\begin{array}{l}\text { przewlekłe zapalenie zatok przynosowych bez } \\
\text { polipów nosa }\end{array}$ \\
\hline CRSWNP & $\begin{array}{c}\text { przewlekłe zapalenie zatok przynosowych } \\
\text { z polipami nosa }\end{array}$ \\
\hline CT & tomografia komputerowa \\
\hline ESS & endoskopowa chirurgia zatok \\
\hline ICD-10 & $\begin{array}{l}\text { Międzynarodowa Statystyczna Klasyfikacja } \\
\text { Chorób i Problemów Zdrowotnych }\end{array}$ \\
\hline ICD-9 & $\begin{array}{c}\text { Międzynarodowa Klasyfikacja Procedur } \\
\text { Medycznych }\end{array}$ \\
\hline$J G P$ & jednorodne grupy pacjentów \\
\hline MPZ & mapy potrzeb zdrowotnych \\
\hline NFZ & Narodowy Fundusz Zdrowia \\
\hline PZZP & przewlekłe zapalenie zatok przynosowych \\
\hline
\end{tabular}

\section{Wstęp}

Przewlekłe zapalenie zatok przynosowych (PZZP) definiuje się jako stan zapalny w nosie i zatokach przynosowych charakteryzujący się obecnością dwóch lub więcej z następujących objawów przez ponad 12 tygodni [1]:

- niedrożność nosa/przekrwienie,

- wydzielina z nosa,

- ból/rozpieranie twarzy,

- zmniejszenie lub utrata węchu.

Obiektywne potwierdzenie rozpoznania wykonuje się za pomocą badania tomografii komputerowej (CT) zatok przynosowych lub endoskopii nosa, które również określają fenotyp: PZZP z polipami nosa (CRSwNP) oraz PZZP bez polipów nosa (CRSsNP). U osób dorosłych polipy nosa powinny być widoczne w obu przewodach nosowych, a jednostronne polipy powinny budzić wątpliwość odnośnie alternatywnej etiologii, chociażby zmiany grzybiczej czy podejrzenia złośliwości zmiany. Polipy nosa są zapalnym przerostem błony śluzowej zatok, najczęściej występują jako obustronne zmiany zapalne. Wśród wszystkich pacjentów z PZZP jedynie około 25-30\% ma CRSwNP. Jednak CRSwNP wiąże się ze znaczną chorobowością i obniżoną jakością życia, przez co choroba ta jest klinicznie ważna pod względem identyfikacji, oceny i leczenia. CRSwNP jest często związane $\mathrm{z}$ astmą oskrzelową i alergicznym nieżytem nosa, ale mechanizmy komórkowe i molekularne, które są przyczyną objawów klinicznych, nie są w pełni rozpoznane. Etiopatogeneza tego schorzenia pozostaje w dużej mierze nieznana. Teorie odnośnie patogenezy PZZP można ogólnie podzielić na związane z czynnikami środowiskowymi i związane z gospodarzem. Hipoteza bariery immunologicznej jest najbardziej szczegółowym i włączającym mechanizmem opisanym w literaturze. Uważa się, że defekty w barierze nabłonka, zwiększona ekspozycja na patogeny i skolonizowane bakterie rozregulowujące układ odpornościowy gospodarza odgrywają ważną rolę w patogenezie choroby $[2,3,4]$.

CRSwNP jest chorobą wieku średniego - typowy wiek diagnozy mieści się w zakresie od 40-60 lat, natomiast średni to 42 lata. Zmiany w nosie wykrywane u pacjentów w wieku poniżej 20 lub powyżej 80 lat budzą podejrzenie innych stanów klinicznych. U dorosłych w zaawansowanym wieku lub w nietypowych lokalizacjach sugerują możliwość występowania nowotworu $[2,3]$.

Mężczyźni są bardziej podatni na występowanie polipów niż kobiety. Według niektórych badaczy to jednak kobiety z CRSwNP mają bardziej zaawansowaną postać choroby niż mężczyźni [2]. W badaniu Stevensa i wsp. [2] $\mathrm{u}$ chorych z CRSwNP poddanych operacji zatok w ośrodku opieki trzeciego stopnia w 2015 roku polipy zdiagnozowano u $38 \%$ kobiet i $62 \%$ mężczyzn. W porównaniu do mężczyzn u kobiet znacznie częściej występowały bardziej zawansowane zmiany radiologiczne związane $\mathrm{z}$ chorobą zatok; kobiety częściej też przyjmowały kortykosteroidy ogólnoustrojowe i częściej konieczna była u nich reoperacja zatok [2].

Benjamin i wsp. [14] podają, że CRSsNP częściej występuje u płci żeńskiej (63\%) w porównaniu z grupą CRSwNP (45\%). Chorobami predysponującymi do CRSsNP są alergiczne i niealergiczne choroby górnych i dolnych dróg oddechowych, zaburzenia funkcji nabłonka, niedobory odporności, choroby autoimmunologiczne i niektóre choroby zakaźne. Dodatkowo w patogenezie CRSsNP istotną rolę odgrywają czynniki środowiskowe i czynniki gospodarza, takie jak: palenie tytoniu, wrodzone wady układu odpornościowego. Według badaczy występowanie CRSsNP spada po 65 roku życia, podczas gdy CRSwNP pozostaje stabilny. Podsumowując, CRSsNP w porównaniu do CRSwNP jest bardziej powszechny we wszystkich grupach wiekowych, ale jego częstość występowania maleje wraz z wiekiem [15]. 
Zgodnie z najnowszymi wytycznymi zarówno miejscowe kortykosteroidy, jak i donosowe irygacje solą fizjologiczną są zalecane jako wstępna terapia medyczna dla pacjentów z CRS [1]. Donosowe kortykosteroidy mogą zmniejszać rozmiar polipów nosa i poprawiać jakość życia pacjentów. Doustne kortykosteroidy mogą również zmniejszać rozmiar polipów i objawy, ale należy zawsze podawać je ostrożnie, biorąc pod uwagę ich ogólnoustrojowe działania niepożądane. Antybiotyki mogą być użyteczne w leczeniu zakaźnych zaostrzeń CRSwNP, ale klinicznie znacząca skuteczność (tj. zmniejszenie polipów) w dużych randomizowanych badaniach jest niewystarczająca $[5,6]$.

Pacjenci z zaawansowanymi zmianami radiologicznymi w CT zatok przynosowych i/lub u których brak poprawy po leczeniu zachowawczym, powinni być oceniani pod kątem chirurgii endoskopowej zatok. Międzynarodowe wytyczne zalecają rozpoczęcie leczenia od co najmniej 1 miesiąca przed rozważeniem operacji [1]. W retrospektywnej analizie opóźnienie endoskopowej chirurgii zatok (ESS) o ponad 5 lat od początkowego rozpoznania CRS było związane z częstszym korzystaniem tych pacjentów z opieki zdrowotnej w okresie pooperacyjnym w porównaniu z pacjentami, którzy mieli wykonaną operację w ciągu 12 miesięcy od diagnozy [7]. Dane te budzą więcej pytań o odpowiedni czas ESS. Polipy nosa mogą nawracać pomimo ESS. Pacjenci cierpiący zarówno na CRSwNP, jak i na astmę oskrzelową wymagają średnio znacznie więcej operacji zatok przynosowych niż pacjenci z samym CRSwNP [7].

Wykazano, że ESS znacznie poprawia jakość życia i jest wskazana u pacjentów z PPZP, u których zawiodła terapia zachowawcza [8]. Rudmik i wsp. wykazali, że w kwestii ekonomicznej ESS jest najbardziej opłacalną interwencją $\mathrm{w}$ porównaniu $\mathrm{z}$ dalszą długoterminową terapią zachowawczą [9].

Endoskopowa chirurgia zatok przeszła wiele udoskonaleń od czasu jej wprowadzenia w latach osiemdziesiątych. Jednym z najbardziej znaczących udoskonaleń było przejście do technik chirurgicznych oszczędzających śluzówkę. Ta ewolucja nastąpiła równolegle $\mathrm{z}$ nowymi odkryciami dotyczącymi funkcji zdrowego i chorego układu zatokowego. Celem procedur chirurgicznych z poprzednich dekad było usunięcia chorej błony śluzowej ze światła zatok. Nawet po wprowadzeniu endoskopu procedury, takie jak etmoidektomia i sphenoidotomia, pozostały zasadniczo podobne do pierwotnego opisu procedury Caldwella-Luca, która zalecała usunięcie całej błony śluzowej zatoki szczękowej. Jednak stopniowo przesunięcie w kierunku zachowania śluzówki stało się częścią praktyki chirurgicznej. Dzisiaj unikanie niepotrzebnych zaburzeń śluzówki podczas ESS pozostaje w większości przypadków właściwe, ponieważ stan zapalny śluzówki jest obecnie rozumiany jako proces potencjalnie odwracalny [10].

Niektórzy pacjenci z PZZP cierpią jednak na nawracające infekcje pomimo leczenia zachowawczego i chirurgicznego. Miejscowa antybiotykoterapia jest obiecującą opcją dla tych pacjentów, ponieważ umożliwia podawanie wyższego stężenia antybiotyku bezpośrednio do źródła infekcji. Ma także tę zaletę, że zmniejsza możliwość skutków niepożądanych przypisywanych ogólnoustrojowej terapii antybiotykowej [6].
ESS jest obecnie akceptowaną interwencją chirurgiczną $\mathrm{w}$ leczeniu opornego na leczenie zachowawcze przewlekłego zapalenia błony śluzowej nosa i zatok przynosowych oraz innych stanów zatok. Metoda jest względnie bezpieczna, jednak możliwe jest wystąpienie zarówno drobnych, jak i ciężkich powikłań, takich jak: wyciek płynu mózgowo-rdzeniowego, uszkodzenie oczodołu lub wewnątrzczaszkowe, zapalenie opon mózgowych, powstanie zrostów, krwawienie. Kennedy i wsp. oraz Cumberworth i wsp. przeprowadzili wczesne niezależne badania dotyczące istotnych odsetek powikłań odnośnie ESS i odnotowali odpowiednio 0,4\% i 0,2\% (badania z 1994 roku) [16,17]. Krings z kolei podaje odsetek powikłań wynoszący $0,36 \%$ - wśród głównych powikłań stwierdzono powikłania z podstawy czaszki $(0,13 \%)$ i powikłania oczodołowe $(0,23 \%)$ [18]. Wizualizacja pola operacyjnego jest niezbędna dla pomyślnego wyniku tej procedury i zminimalizowania rozwoju powikłań. Krwawienie w polu chirurgicznym może być progresywne, a nawet szkodliwe, powodując przedłużony czas operacji, niepełne interwencje chirurgiczne i zwiększone powikłania wynikające $\mathrm{z}$ trudności $\mathrm{z}$ wizualizacją i identyfikacją punktów orientacyjnych z późniejszym uszkodzeniem ważnych struktur anatomicznych.

\section{Materiały i metody}

Niniejsze opracowanie powstało na podstawie map potrzeb zdrowotnych (MPZ) [12], które są publikowane na podstawie art. 95a Ustawy z dnia 27 sierpnia $2004 \mathrm{r}$. o świadczeniach opieki zdrowotnej finansowanych ze środków publicznych (Dz.U. z 2017 r. poz. 1938, z późn. zm.) oraz zgodnie z zaakceptowanym przez Komisję Europejską dokumentem „Krajowe ramy strategiczne. Policy Paper dla ochrony zdrowia na lata 2014-2020". Zakres informacji zawartych w MPZ wynika z Rozporządzenia Ministra Zdrowia z dnia 26 marca 2015 r. w sprawie zakresu treści map potrzeb zdrowotnych (Dz.U. poz. 458). Zgodnie $\mathrm{z}$ treścią $\mathrm{ww}$. rozporządzenia MPZ składają się z trzech części: analizy demograficznej i epidemiologicznej, analizy stanu i wykorzystania zasobów oraz prognoz potrzeb zdrowotnych. MPZ powstały jako wynik współpracy ekspertów medycznych i ekspertów zdrowia publicznego, przedstawicieli środowiska medycznego, wojewódzkich rad ds. potrzeb zdrowotnych oraz konsultantów krajowych. W grudniu 2016 roku opublikowano MPZ $\mathrm{w}$ podziale na dwa moduły (A i B) dla 30 różnych grup chorób na podstawie jednostkowych danych o świadczeniach wykazanych przez świadczeniodawców do Narodowego Funduszu Zdrowia (NFZ), odrębnie dla każdego województwa. $\mathrm{W}$ ramach grupy $\mathrm{B}$ wyodrębniono choroby nosa, zatok przynosowych, ucha, gardła i krtani. W pracy wykorzystano dane dostępne na stronie Ministerstwa Zdrowia [12]. Opracowanie obejmuje dane za rok 2014 oraz stanowi rozszerzenie i uszczegółowienie MPZ w wybranych aspektach.

\section{Wyniki}

W roku 2014 w Polsce współczynnik zapadalności na choroby nosa, zatok przynosowych, ucha, gardła i krtani wynosił 5762,8 na 100 tys. ludności, a współczynnik chorobowości - 41258,7 na 100 tys. Odnotowano 5,132 mln porad ambulatoryjnych z powodu powyższych schorzeń, 
z czego 47,5\% to porady pacjentów, którzy pojawili się co najmniej 3 razy. Najwyższą liczbę hospitalizacji odnotowano w województwie mazowieckim (58,7 tys.), a najniższą - w lubuskim (6,2 tys.). W przypadku osób dorosłych najwyższą liczbę hospitalizacji, tj. 30,5 tys., odnotowano $\mathrm{w}$ województwie mazowieckim, a najniższą - w lubuskim (3,6 tys.). Liczba hospitalizacji w przypadku dzieci w województwie mazowieckim wynosiła 28,3 tys., a lubuskim - 2,6 tys. Najwyższe saldo migracji zaobserwowano w województwie mazowieckim, a najniższe w małopolskim. Z powodu chorób nosa, zatok przynosowych,

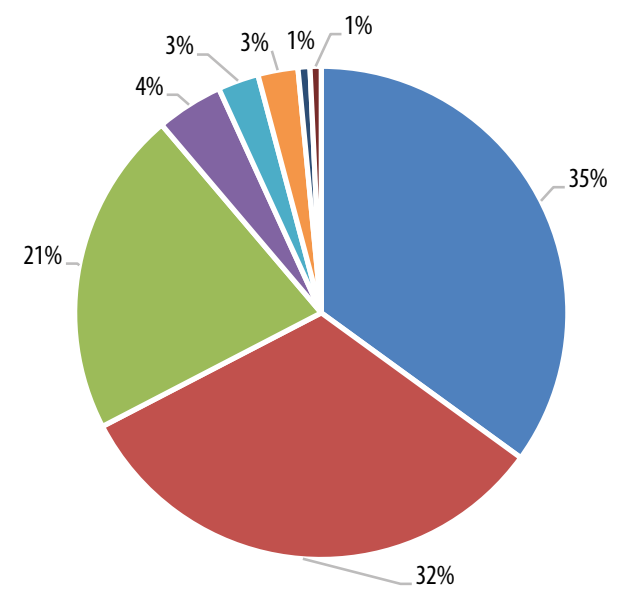

- $J 32.8$

- $J 32.0$

- 332.4

- 332.2

- $\mathrm{J32}$

- $\mathrm{J} 32.9$

- $J 32.1$

- 332.3

Rycina 1. Struktura hospitalizacji według głównej przyczyny. Figure 1. The structure of hospitalizations according to the main cause. ucha, gardła i krtani zarejestrowano 154,5 tys. hospitalizacji o charakterze zabiegowym. Największy udział hospitalizacji o charakterze zabiegowym wykazano w przypadku chorób nosa i zatok przynosowych $(79,8 \%)$, a najniższy w przypadku zaburzeń głosu, mowy i języka $(8,4 \%)$ [12].

W niniejszej pracy przedstawiono analizę map potrzeb zdrowotnych dotyczącą chorób zatok przynosowych z poszczególnych 16 województw w zakresie lecznictwa szpitalnego. Skupiono się na rozpoznaniu J32 z dalszymi rozwinięciami według Międzynarodowej Klasyfikacji Chorób i Problemów Zdrowotnych (ICD-10). Zapadalność rejestrowana dla rozpoznań z grupy „Choroby nosa i zatok przynosowych” w roku 2014 wyniosła 635,7 tys. przypadków w Polsce. Współczynnik zapadalności rejestrowanej na 100 tys. ludności wyniósł 1 652,4. Natomiast współczynnik chorobowości oszacowano na 12 167,3 na 100 tys. osób [12]. Najczęstszą przyczyną hospitalizacji było rozpoznanie J32.8 - „Inne przewlekłe zapalenie zatok” (5,8 tys. hospitalizacji), J32.0 - „Przewlekłe zapalenie zatok szczękowych" (5,4 tys. hospitalizacji) oraz J32.4 - „Przewlekłe zapalenie wszystkich zatok przynosowych" (3,6 tys. hospitalizacji). Stosunek częstości hospitalizacji według głównej przyczyny przedstawia rycina 1 .

Strukturę liczby hospitalizacji w ciągu roku w stosunku do wieku chorych przedstawiono na rycinie 2. Najwięcej hospitalizacji (tj. powyżej 300 hospitalizacji/rok) odnotowano wśród pacjentów w wieku 29-44 lata oraz 51-65 lat, natomiast liczba hospitalizacji znacząco zmniejsza się po 66. roku życia.

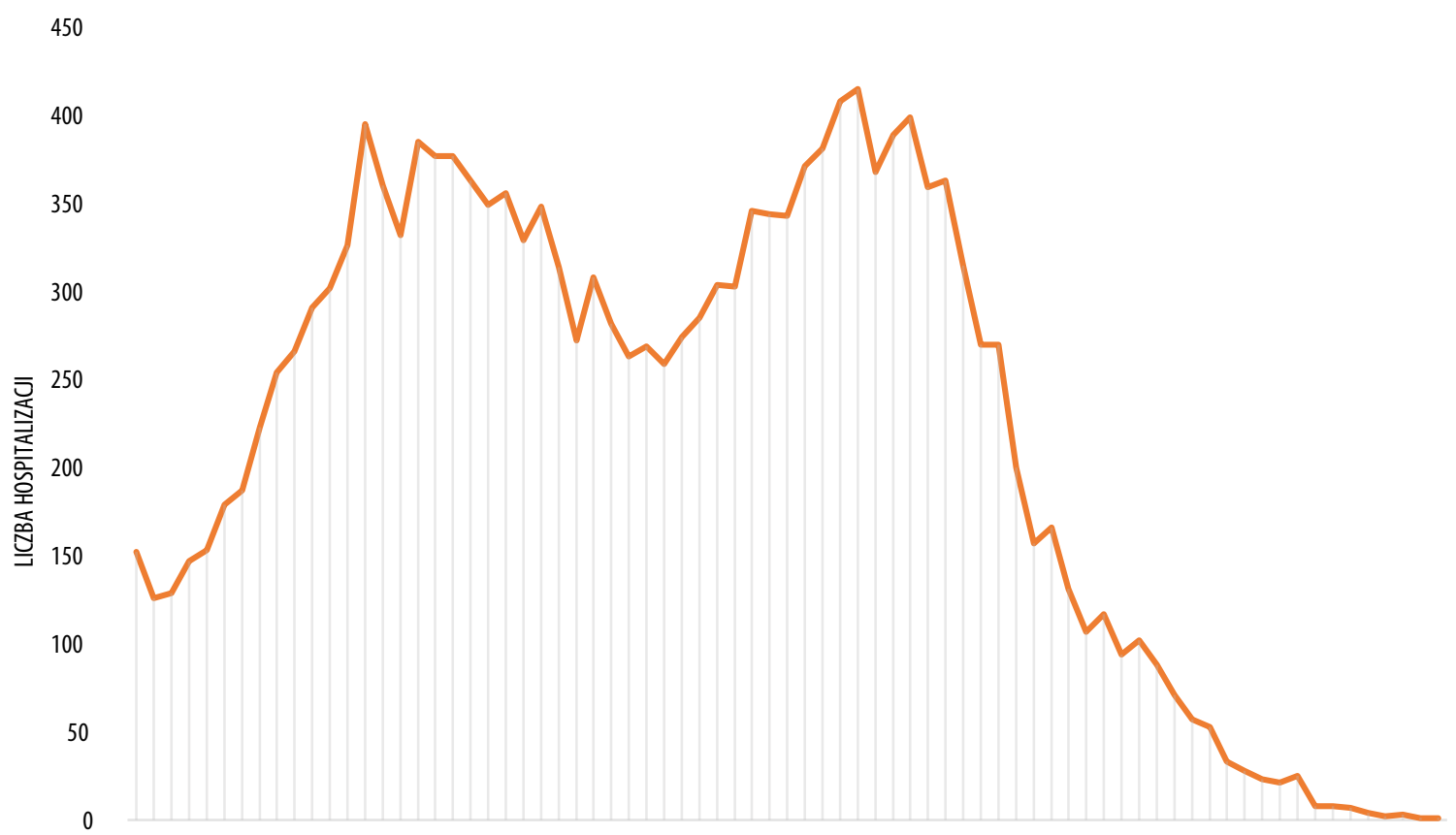

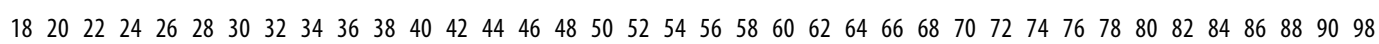
WIEK PAOJENTA (W LATACH)

Rycina 2. Struktura hospitalizacji według wieku pacjenta.

Figure 2. The structure of hospitalizations according to patient's age. 
W tabeli 1. przedstawiono analizę liczby hospitalizacji, liczby pacjentów, stosunku liczby hospitalizacji spoza województwa, średniego wieku pacjentów i średniej długości hospitalizacji we wszystkich województwach. Największą liczbę hospitalizacji odnotowano w województwie mazowieckim (3,95 tys.), natomiast najmniejszą - w lubuskim (100). Jednocześnie największą liczbę ponownych hospitalizacji stwierdzono w województwie świętokrzyskim $(8,9 \%)$, podczas gdy w województwie lubuskim nie odnotowano rehospitalizacji. Rycina 3. przedstawia analizę migracji pacjentów w województwach. Największy odsetek hospitalizacji spoza województwa zaobserwowano w województwie kujawsko-pomorskim (59,3\%), a najmniejszy - w zachodniopomorskim (4,87\%). Średni wiek pacjenta dla wszystkich województw wynosił 47,7 lat. Średnia długość hospitalizacji wahała się w granicach od 2 dni (woj. pomorskie) do 5 dni (woj. lubuskie).

Na rycinie 4. przedstawiono analizę czasu trwania hospitalizacji w przypadku pacjentów z chorobami zatok przynosowych. Najczęściej leczenie szpitale zostało zakończone w 4 . dobie (w 4 tys. przypadków). Średni czas hospitalizacji wynosił 4,2 dnia.

Rycina 5. prezentuje strukturę hospitalizacji ze względu wykonane procedury zabiegowe zgodnie $\mathrm{z}$ jednorodnymi grupami pacjentów (JGP). JGP są sposobem rozliczania usług zdrowotnych przez płatnika - Narodowy Fundusz Zdrowia. Rodzaj hospitalizacji zabiegowych oraz typ procedur operacyjnych w zakresie chorób zatok przynosowych i nosa przedstawiono w tabeli 2.
Zgodnie z ryciną 5. najczęściej wykorzystywaną grupą JGP do sprawozdawania hospitalizacji w analizowanej grupie rozpoznań była C41 - „Kompleksowe zabiegi nosa” $(60,94 \%$ hospitalizacji sprawozdanych z JGP). W województwach: śląskim, małopolskim, wielkopolskim i dolnośląskim sprawozdano także hospitalizacje zabiegowe diagnostyczne, przy czym ich udział nie przekroczył 0,2\% w każdym z nich.

Rycina 3. Migracje pacjentów w obrębie województw.

Figure 3. Migrations of patients within voivodships.

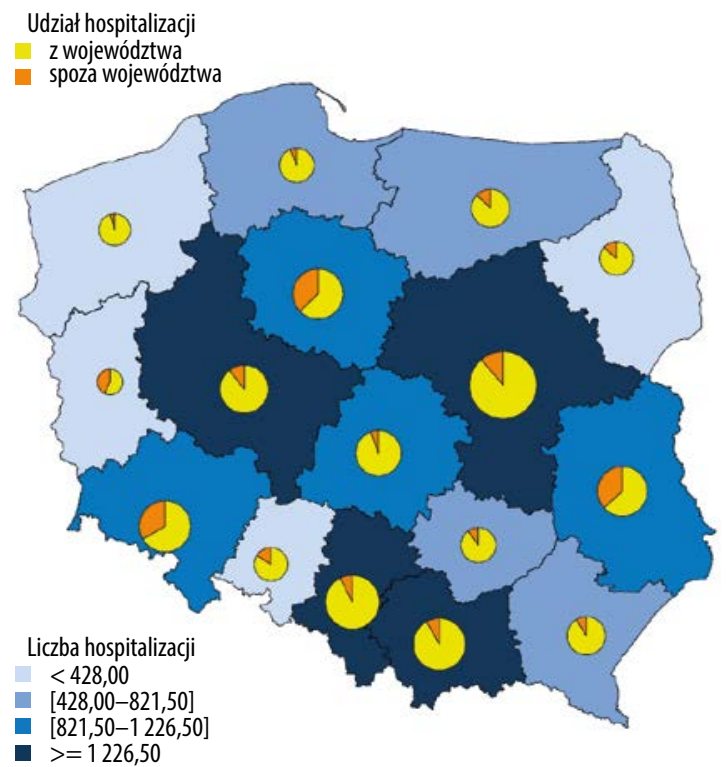

Tabela 1. Liczba hospitalizacji w województwach oraz struktura hospitalizacji względem miejsca zamieszkania pacjenta.

Table 1. The number of hospitalizations in voivodships and the structure of hospitalization in relation to the place of residence of the patient.

\begin{tabular}{|c|c|c|c|c|c|}
\hline Województwo & $\begin{array}{c}\text { Liczba } \\
\text { hospitalizacji } \\
\text { (w tys.) }\end{array}$ & $\begin{array}{l}\text { Liczba pacjentów } \\
\text { (w tys.) }\end{array}$ & $\begin{array}{c}\text { Procent } \\
\text { hospitalizacji } \\
\text { spoza woj. (w \%) }\end{array}$ & $\begin{array}{c}\text { Średni wiek } \\
\text { pacjenta } \\
\text { (w latach) }\end{array}$ & $\begin{array}{l}\text { Średnia długość } \\
\text { hospitalizacji } \\
\text { (w dniach) }\end{array}$ \\
\hline Mazowieckie & 3,95 & 3,85 & 12,71 & 46 & 3,0 \\
\hline Śląskie & 1,99 & 1,93 & 7,96 & 47 & 2,7 \\
\hline Małopolskie & 1,74 & 1,71 & 8,79 & 46 & 3,8 \\
\hline Wielkopolskie & 1,30 & 1,26 & 11,82 & 48 & 3,8 \\
\hline Dolnośląskie & 1,20 & 1,15 & 49,88 & 49 & 3,8 \\
\hline Łódzkie & 1,13 & 1,09 & 5,73 & 49 & 3,3 \\
\hline Kujawsko-pomorskie & 1,05 & 1,03 & 59,30 & 46 & 2,6 \\
\hline Lubelskie & 1,02 & 1,00 & 57,93 & 48 & 4,6 \\
\hline Podkarpackie & 0,62 & 0,59 & 9,50 & 48 & 3,2 \\
\hline Warmińsko-mazurskie & 0,59 & 0,58 & 14,58 & 47 & 2,8 \\
\hline Pomorskie & 0,45 & 0,44 & 6,46 & 48 & 2,0 \\
\hline Świętokrzyskie & 0,45 & 0,41 & 11,24 & 48 & 3,2 \\
\hline Podlaskie & 0,38 & 0,36 & 15,65 & 48 & 3,8 \\
\hline Opolskie & 0,37 & 0,35 & 19,18 & 50 & 4,0 \\
\hline Zachodnio- pomorskie & 0,35 & 0,34 & 4,87 & 47 & 3,5 \\
\hline Lubuskie & 0,10 & 0,10 & 75,25 & 48 & 5,0 \\
\hline
\end{tabular}




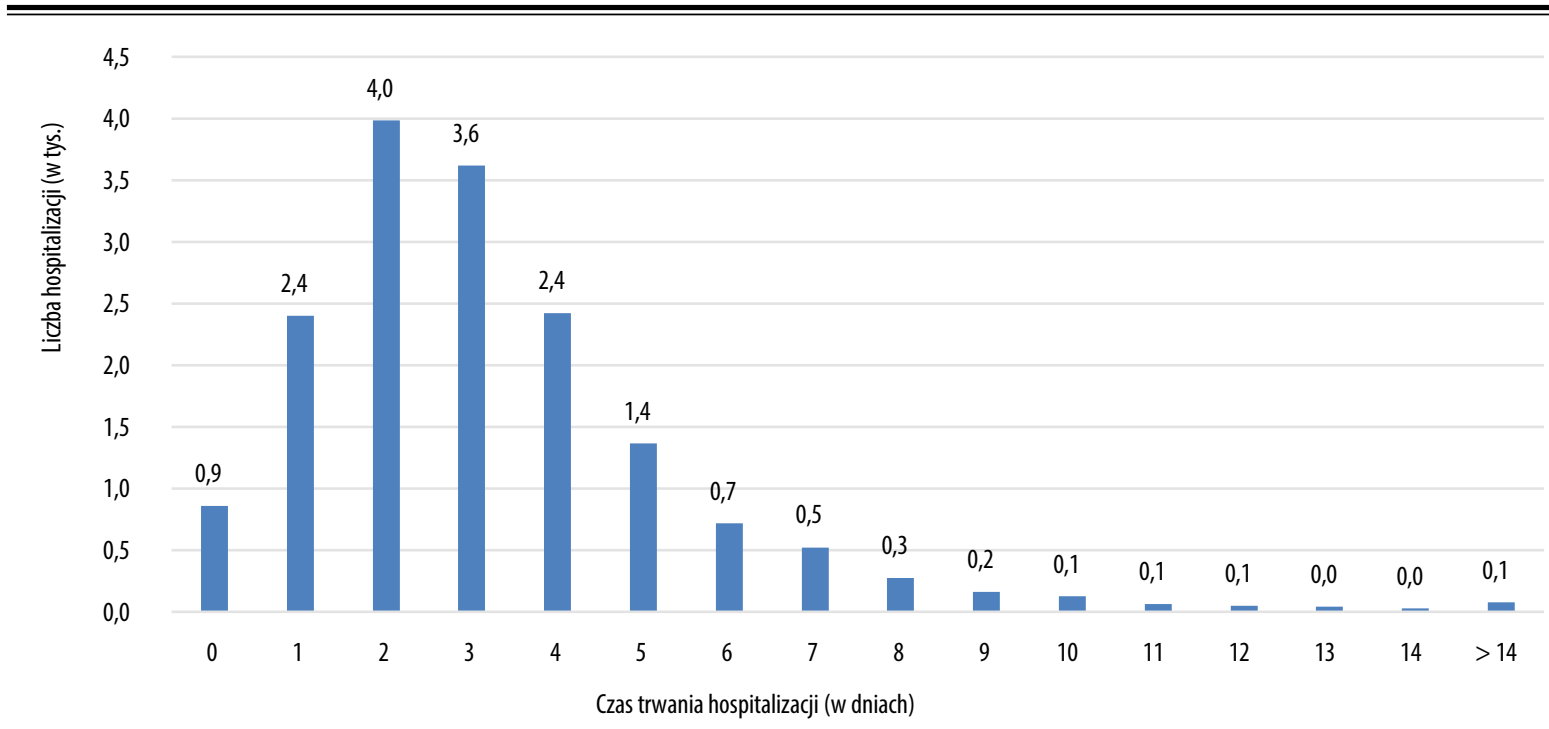

Rycina 4. Liczba hospitalizacji w zależności od czasu trwania.

Figure 4. The number of hospitalizations depending on the duration.

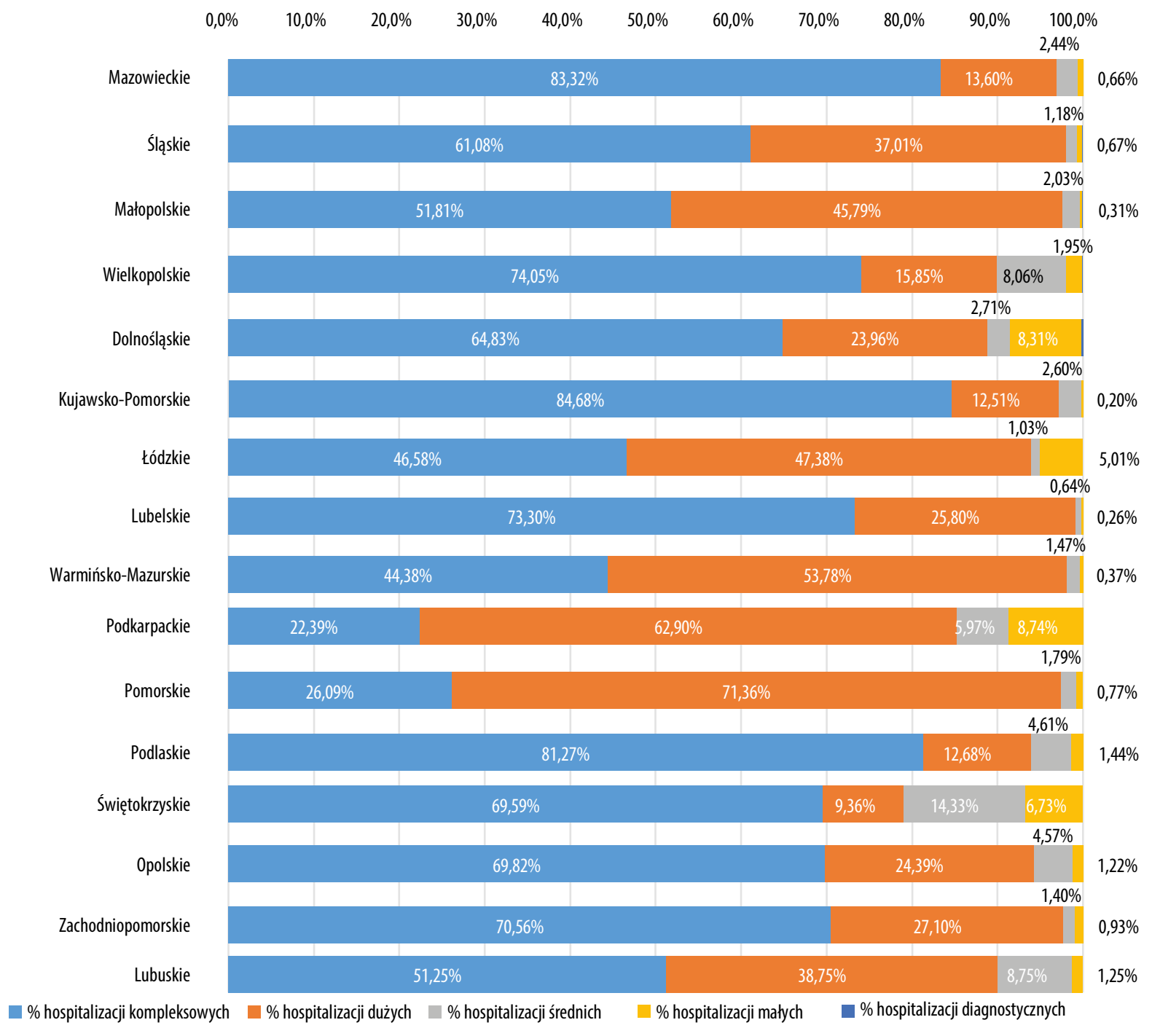

Rycina 5. Struktura hospitalizacji JGP zabiegowych według województw.

Figure 5. The structure of hospitalizations by JGP in voivodships. 
Tabela 2. Rodzaj hospitalizacji zabiegowych według JGP oraz typ procedur operacyjnych ICD-9.

Table 2. The type of hospitalizations according to JGP and the type of ICD-9 procedures.

\begin{tabular}{|c|c|c|c|c|c|}
\hline$\underset{\text { JGP }}{\text { Grupa }}$ & $\begin{array}{l}\text { Kod } \\
\text { ICD-9 }\end{array}$ & Nazwa & $\underset{\text { JGP }}{\text { Grupa }}$ & $\begin{array}{l}\text { Kod } \\
\text { ICD-9 }\end{array}$ & Nazwa \\
\hline \multirow{15}{*}{ 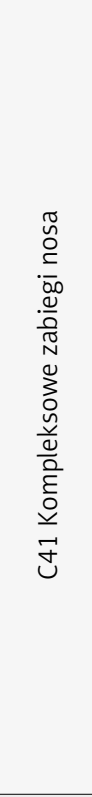 } & 21.04 & Podwiązanie tt. sitowych przy krwotoku z nosa & \multirow{15}{*}{ 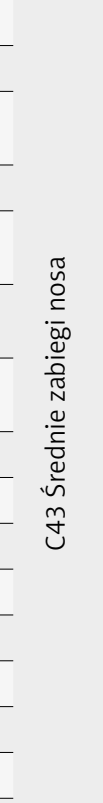 } & 09.48 & $\begin{array}{l}\text { Endoskopowe wytworzenie przetoki } \\
\text { nosowo-tzowej }\end{array}$ \\
\hline & $\begin{array}{l}21.05 \\
21.06\end{array}$ & $\begin{array}{c}\text { Podwiązanie t. szczękowej przy krwotoku z nosa } \\
\text { Podwiązanie t. szyjnej zewnętrznej przy krwotoku } \\
\text { z nosa }\end{array}$ & & 21.07 & $\begin{array}{c}\text { Wycięcie śluzówki/ przeszczep skóry na } \\
\text { przegrodę i boczną ścianę nosa przy krwotoku } \\
\text { z nosa }\end{array}$ \\
\hline & 21.4 & Resekcja nosa & & 21.311 & Wycięcie polipa nosa \\
\hline & 21.831 & $\begin{array}{c}\text { Rekonstrukcja nosa uszypułowanym płatem } \\
\text { z ramienia }\end{array}$ & & 21.38 & $\begin{array}{l}\text { Endoskopowe miejscowe wycięcie lub zniszczenie } \\
\text { zmiany nosa }\end{array}$ \\
\hline & 21.832 & $\begin{array}{l}\text { Rekonstrukcja nosa uszypułowanym płatem } \\
\text { z czoła }\end{array}$ & & 21.5 & Podśluzówkowe wycięcie przegrody nosowej \\
\hline & & Rekonstrukcja przegrody nosowej z dojścia & & 21.87 & Endoskopowa plastyka przegrody nosa \\
\hline & 21.893 & zewnętrznego & & 21.892 & Korekcyjna plastyka pourazowego \\
\hline & 22.41 & Otwarcie zatoki czołowej & & & acis \\
\hline & 22.421 & Wycięcie zmiany zatoki czołowej & & 21.899 & Uperacje nosa (plastyka/rekonstrukcja) - inne \\
\hline & 22.422 & Obliteracja zatoki czołowej tkanką tłuszczową & & 22.18 & Endoskopowa biopsja zatoki nosa \\
\hline & 22.51 & Otwarcie komórek sitowych & & 22.59 & Otwarcie zatoki nosa - inne \\
\hline & 22.52 & Otwarcie zatoki klinowej & & 22.62 & $\begin{array}{l}\text { Wycięcie zmiany zatoki szczękowej } \\
- \text { z innego dostępu }\end{array}$ \\
\hline & 22.53 & Otwarcie wielu zatok nosa & & 22.69 & Wycięcie zatoki nosa - inne \\
\hline & 22.63 & Wycięcie komórek sitowych & & 22.91 & Wyłonienie zatoki szczękowej \\
\hline & 22.64 & Usunięcie zatoki klinowej & & 22.92 & Wytworzenie przetoki zatoki \\
\hline \multirow{27}{*}{ 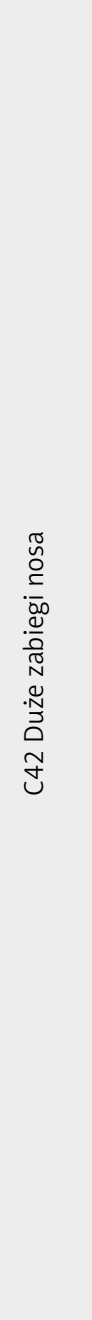 } & 21.72 & Otwarte nastawienie złamania nosa & \multirow{20}{*}{ 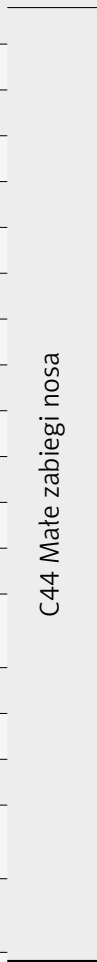 } & 21.02 & Tylna i przednia tamponada nosa przy krwotoku \\
\hline & 21.821 & Wycięcie przetoki nosowo-wargowej & & 21.03 & Przyżeganie przy krwotoku z nosa i tamponada \\
\hline & 21.822 & Wycięcie przetoki nosowo-gardłowej & & 21.11 & Nacięcie chrząstki nosa \\
\hline & 21.823 & Wycięcie przetoki nosowo-ustnej & & 21.12 & Nacięcie skóry nosa \\
\hline & 21.841 & Plastyka przegrody nosowej & & 21.13 & Nacięcie przegrody nosowej \\
\hline & 21.842 & Plastyka skośnego nosa & & 21.14 & Drenaż ropnia przegrody nosa \\
\hline & 21.851 & Powiększenie nosa przeszczepem & & 21.18 & Endoskopowy drenaż ropnia przegrody nosa \\
\hline & 21.852 & Powiększenie nosa sztucznym wszczepem & & 21.293 & Rinoskopia tylna \\
\hline & 21.861 & Plastyka nosa płatami nosowo-wargowymi & & 21.30 & Wycięcie lub zniszczenie zmiany nosa \\
\hline & 21.862 & Plastyka koniuszka nosa & & & nieokreślone inaczej \\
\hline & 21.881 & Zmiażdżenie przegrody nosowej & & 21.32 & $\begin{array}{c}\text { Miejscowe wycięcie lub zniszczenie innych } \\
\text { zmian nosa }\end{array}$ \\
\hline & $\begin{array}{l}21.882 \\
21.891\end{array}$ & $\begin{array}{l}\text { Zamknięcie perforacji przegrody } \\
\text { Przyszycie amputowanego nosa }\end{array}$ & & 21.61 & $\begin{array}{l}\begin{array}{l}\text { Wycięcie matżowiny nosa (diatermia/krioterapia/ } \\
\text { laserochirurgia) }\end{array}\end{array}$ \\
\hline & 21.892 & Korekcyjna plastyka pourazowego & & 21.69 & Wycięcie małżowiny nosa - inne \\
\hline & & $\begin{array}{c}\text { zniekształcenia nosa } \\
\end{array}$ & & 21.71 & Zamknięte nastawienie złamania nosa \\
\hline & 21.899 & Operacje nosa (plastyka/rekonstrukcja) - inne & & 21.81 & Szycie rany nosa \\
\hline & 22.12 & Otwarta biopsja zatoki nosa & & 21.91 & Uwolnienie zrostów nosowych \\
\hline & 22.2 & Antrotomia przeznosowa & & 21.98 & Endoskopowe uwolnienie zrostów nosowych \\
\hline & 22.311 & $\begin{array}{c}\text { Usunięcie wyściółki zatoki drogą zabiegu } \\
\text { Caldwella-Luc’a }\end{array}$ & & 22.00 & Aspiracja/ płukanie zatok nosa-inne \\
\hline & 22.391 & Otwarcie zatoki szczękowej z dostępu & & 22.11 & Zamknięta igłowa biopsja zatoki nosa \\
\hline & & Caldwella-Luc'a & & 33.239 & Bronchoskopia - inna \\
\hline & 22.58 & Endoskopowe otwarcie wielu zatok nosa & & & \\
\hline & 22.61 & $\begin{array}{l}\text { Wycięcie zmiany zatoki szczękowej z dostępu } \\
\text { Caldwella-Luc'a }\end{array}$ & & & \\
\hline & 22.69 & Wycięcie zatoki nosa - inne & & & \\
\hline & 22.71 & Zamknięcie przetoki zatoki nosa & & & \\
\hline & 22.791 & Rekonstrukcja przewodu zatokowo-nosowego & & & \\
\hline & 22.792 & Zabieg naprawczy kości zatoki dodatkowej & & & \\
\hline & 29.48 & $\begin{array}{c}\text { Endoskopowa operacja niewykształcenia } \\
\text { nozdrzy tylnych }\end{array}$ & & & \\
\hline
\end{tabular}


Tabela 3. Dominujące procedury w województwach.

Table 3. Dominant procedures in voivodships.

\begin{tabular}{|c|c|c|c|c|c|c|c|c|c|c|c|c|c|c|c|c|c|}
\hline Procedura ICD-9 & $\begin{array}{l}\vec{a} \\
\stackrel{0}{E} \\
\stackrel{5}{5}\end{array}$ & $\begin{array}{l}\frac{0}{\frac{v}{n}} \\
\frac{\tilde{n}}{\tilde{n}} \\
\frac{0}{\circ} \\
\frac{0}{0}\end{array}$ & 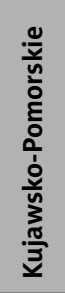 & $\begin{array}{l}\frac{0}{\frac{0}{n}} \\
\frac{\omega}{0} \\
\frac{0}{3}\end{array}$ & 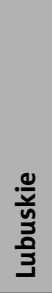 & $\begin{array}{l}\frac{0}{\frac{N}{N}} \\
\frac{0}{0} \\
\stackrel{+}{*}\end{array}$ & $\begin{array}{l}\frac{0}{\frac{0}{u}} \\
\frac{0}{0} \\
\frac{0}{0} \\
\frac{\pi}{i}\end{array}$ & 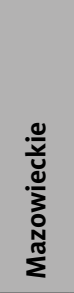 & $\begin{array}{l}\frac{0}{} \\
\frac{0}{\circ} \\
\frac{0}{0}\end{array}$ & $\begin{array}{l}\frac{0}{0} \\
\frac{0}{0} \\
\frac{0}{\pi} \\
\frac{0}{0} \\
\stackrel{0}{0}\end{array}$ & $\begin{array}{l}\frac{0}{v} \\
\frac{\tilde{v}}{\tilde{0}} \\
\frac{0}{0}\end{array}$ & $\begin{array}{l}\frac{0}{\frac{y}{u}} \\
\frac{0}{0} \\
\frac{0}{0}\end{array}$ & $\frac{\frac{0}{\frac{v}{n}}}{\frac{\pi}{n}}$ & 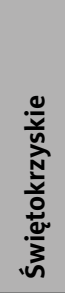 & 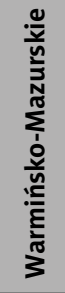 & $\begin{array}{l}\frac{0}{0} \\
\frac{u}{0} \\
\frac{0}{0} \\
\overline{0} \\
\frac{0}{3}\end{array}$ & 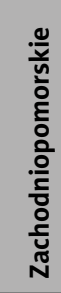 \\
\hline 22.53 Otwarcie wielu zatok nosa & 7931 & 574 & 488 & 409 & 37 & 184 & 740 & 2871 & 175 & 54 & 177 & 40 & 1057 & 235 & 162 & 618 & 110 \\
\hline 21.841 Plastyka przegrody nosowej & 1877 & 130 & 139 & 107 & 7 & 59 & 101 & 778 & 94 & 40 & 50 & 28 & 69 & 31 & 37 & 197 & 10 \\
\hline $\begin{array}{l}22.58 \text { Endoskopowe otwarcie wielu zatok } \\
\text { nosa }\end{array}$ & 1855 & 103 & 22 & 55 & 9 & 159 & 866 & 74 & 58 & 80 & 6 & 125 & 177 & 16 & 100 & 2 & 3 \\
\hline 22.51 Otwarcie komórek sitowych & 1054 & 108 & 29 & 145 & 1 & 105 & 13 & 116 & 55 & 62 & 106 & 13 & 25 & 2 & 22 & 232 & 20 \\
\hline 22.63 Wycięcie komórek sitowych & 974 & 69 & 315 & 27 & & 231 & 87 & 6 & & 20 & 2 & 42 & 2 & 89 & 69 & & 15 \\
\hline 21.311 Wycięcie polipa nosa & 972 & 98 & 32 & 60 & 6 & 14 & 122 & 178 & 82 & 62 & 61 & 8 & 58 & 45 & 21 & 118 & 7 \\
\hline $\begin{array}{l}21.61 \text { Wycięcie małżowiny nosa } \\
\text { (diatermia/ krioterapia/ laserochirurgia) }\end{array}$ & 890 & 105 & 138 & 98 & 5 & 3 & 29 & 370 & & 9 & 3 & 6 & 14 & 3 & 48 & 49 & 10 \\
\hline $\begin{array}{l}22.61 \text { Wycięcie zmiany zatoki szczękowej } \\
\text { z dostępu Caldwella-Luc'a }\end{array}$ & 869 & 43 & 45 & 31 & 7 & 80 & 64 & 157 & 15 & 22 & 5 & 36 & 165 & 4 & 126 & 54 & 15 \\
\hline $\begin{array}{l}\text { 22.391 Otwarcie zatoki szczękowej } \\
\text { z dostępu Caldwella-Luc'a }\end{array}$ & 734 & 63 & 41 & 113 & 4 & 13 & 50 & 39 & 12 & 86 & 25 & 25 & 111 & 5 & 45 & 88 & 14 \\
\hline 22.2 Antrotomia przeznosowa & 617 & 60 & 2 & 153 & & 41 & 24 & 128 & & 27 & 102 & 1 & 10 & 2 & 11 & 32 & 24 \\
\hline $\begin{array}{l}22.311 \text { Usunięcie wyściółki zatoki drogą } \\
\text { zabiegu Caldwella-Luc’a }\end{array}$ & 425 & 39 & 3 & 10 & 9 & 11 & 33 & 44 & 20 & 74 & 1 & 11 & 94 & 4 & 31 & 22 & 19 \\
\hline 21.69 Wycięcie małżowiny nosa - inne & 293 & 19 & 4 & 7 & & 6 & 18 & 28 & 4 & & 25 & 10 & 4 & 3 & 5 & 150 & 10 \\
\hline $\begin{array}{l}22.01 \text { Punkcja zatoki nosa/ płukanie/ } \\
\text { aspiracja }\end{array}$ & 247 & 18 & & 11 & & 43 & 4 & 5 & 7 & 58 & 5 & 1 & 33 & 27 & & 30 & 5 \\
\hline $\begin{array}{l}21.01 \text { Przednia tamponada nosa przy } \\
\text { krwotoku }\end{array}$ & 245 & 31 & & 18 & & 56 & 97 & 2 & & & 1 & & 32 & 2 & & 6 & \\
\hline 22.52 Otwarcie zatoki klinowej & 191 & 23 & 7 & 12 & 1 & 4 & 3 & 43 & & 5 & 38 & 3 & & 1 & 11 & 32 & 8 \\
\hline $\begin{array}{l}22.00 \text { Aspiracja/ płukanie zatok nosa } \\
\text { - inne }\end{array}$ & 187 & 80 & 2 & 6 & 1 & 3 & 3 & 11 & 2 & 2 & 2 & & 42 & 21 & & 11 & 1 \\
\hline 22.71 Zamknięcie przetoki zatoki nosa & 166 & 5 & & 8 & 2 & 15 & 2 & 1 & 4 & 6 & 3 & 84 & 1 & 1 & 8 & 18 & 8 \\
\hline 22.41 Otwarcie zatoki czołowej & 137 & 3 & 11 & 13 & 3 & 2 & 2 & 17 & & & 52 & 1 & 5 & 1 & 2 & 21 & 4 \\
\hline $\begin{array}{l}\text { 22.62 Wycięcie zmiany zatoki szczękowej } \\
\text { - z innego dostępu }\end{array}$ & 128 & 6 & 2 & & & 4 & 15 & 44 & 7 & 5 & 1 & 1 & 18 & 1 & 12 & 11 & 1 \\
\hline $\begin{array}{l}22.31 \text { Radykalna antrotomia (otwarcie) } \\
\text { zatoki szczękowej }\end{array}$ & 101 & & & & & 1 & & 1 & 1 & 2 & & 1 & & 1 & & 94 & \\
\hline
\end{tabular}

Natomiast w tabeli 3. zamieszono dominujące procedury zabiegowe zgodnie z Międzynarodową Klasyfikacją Procedur Medycznych (ICD-9) z zakresu leczenia chorób zatok, których suma wykonań w Polsce w 2014 roku wyniosła powyżej 100. Najczęściej wykonywaną procedurą raportowaną do NFZ było „Otwarcie wielu zatok nosa” (ICD-9 22.53). Najwięcej tego typu operacji wykonano kolejno w województwach: mazowieckim, śląskim i wielkopolskim.

Tabela 4. przedstawia zestawienie świadczeniodawców, którzy sprawozdali ponad 200 hospitalizacji z zakresu chorób zatok przynosowych i nosa w 2014 roku. Wiodącymi ośrodkami, w których odnotowano ok. 500 hospitalizacji, były: SPZOZ Szpital Uniwersytecki w Krakowie, z czego
97,89\% hospitalizacji sprawozdano zgodnie z JGP, 5. Wojskowy Szpital Kliniczny z Polikliniką SPZOZ w Krakowie - 98,29\% oraz Szpital Kliniczny im. H. Święcickiego Uniwersytetu Medycznego im. K. Marcinkowskiego w Poznaniu - 100\%.

W tabeli 5. przedstawiono najczęściej wykonywane procedury zabiegowe $\mathrm{w}$ zakresie chorób zatok przynosowych i nosa w trzech grupach wiekowych: (1) 18-44 lata, (2) 45-69 lat oraz (3) 70 lat i więcej. Najczęściej wykonywaną procedurą raportowaną do NFZ we wszystkich grupach wiekowych było „Otwarcie wielu zatok nosa”, jednocześnie wykonywano ją najczęściej w drugiej grupie wiekowej. 
Tabela 4. Świadczeniodawcy, którzy sprawozdali powyżej 200 hospitalizacji z analizowanego zakresu.

Table 4. Providers who reported more than 200 hospitalizations from the analyzed range.

\begin{tabular}{|c|c|c|c|c|c|}
\hline Nazwa świadczeniodawcy & Województwo & $\begin{array}{l}\text { Liczba } \\
\text { hospitalizacji } \\
\text { (w tys.) }\end{array}$ & $\begin{array}{l}\text { Hospitalizacje } \\
\text { nie JGP } \\
\text { (w \%) }\end{array}$ & $\begin{array}{l}\text { Hospitalizacje } \\
\text { JGP } \\
\text { (w \%) }\end{array}$ & $\begin{array}{l}\text { Hospitalizacje } \\
\text { JGP zabieg. } \\
\text { (w \%) }\end{array}$ \\
\hline $\begin{array}{l}\text { SPZOZ Szpital Uniwersytecki } \\
\text { w Krakowie }\end{array}$ & Małopolskie & 0,5 & 2,11 & 97,89 & 89,83 \\
\hline $\begin{array}{l}\text { 5. Wojskowy Szpital Kliniczny } \\
\text { z Polikliniką - SPZOZ w Krakowie }\end{array}$ & Małopolskie & 0,5 & 1,71 & 98,29 & 98,08 \\
\hline $\begin{array}{l}\text { Szpital Kliniczny im. H. Święcickiego } \\
\text { Uniwersytetu Medycznego } \\
\text { im. K. Marcinkowskiego w Poznaniu }\end{array}$ & Wielkopolskie & 0,5 & 0,00 & 100,00 & 90,73 \\
\hline $\begin{array}{l}\text { Instytut Fizjologii i Patologii Słuchu } \\
\text { Kajetany/Warszawa }\end{array}$ & Mazowieckie & 0,4 & 0,98 & 99,02 & 99,02 \\
\hline $\begin{array}{l}\text { Centralny Szpital Kliniczny MSW } \\
\text { w Warszawie }\end{array}$ & Mazowieckie & 0,3 & 0,00 & 100,00 & 97,09 \\
\hline $\begin{array}{l}\text { Szpital Specjalistyczny } \\
\text { im. L. Rydygiera w Krakowie Sp. z o.o. }\end{array}$ & Małopolskie & 0,3 & 0,00 & 100,00 & 98,74 \\
\hline $\begin{array}{l}\text { Szpital Czerniakowski SPZOZ } \\
\text { w Warszawie }\end{array}$ & Mazowieckie & 0,3 & 0,32 & 99,68 & 89,59 \\
\hline $\begin{array}{l}\text { SP Szpital Kliniczny Nr } 7 \text { ŚUM } \\
\text { w Katowicach Górnośląskie Centrum } \\
\text { Medyczne im. prof. L. Gieca }\end{array}$ & Śląskie & 0,3 & 1,73 & 98,27 & 94,12 \\
\hline $\begin{array}{l}\text { SPZOZ Uniwersytecki Szpital Kliniczny } \\
\text { im. WAM UM w todzi - Centralny } \\
\text { Szpital Weteranów }\end{array}$ & Łódzkie & 0,3 & 2,10 & 97,90 & 95,45 \\
\hline Szpital Wojewódzki w Poznaniu & Wielkopolskie & 0,3 & 0,36 & 99,64 & 70,25 \\
\hline $\begin{array}{l}\text { Samodzielny Publiczny Centralny } \\
\text { Szpital Kliniczny w Warszawie }\end{array}$ & Mazowieckie & 0,3 & 0,00 & 100,00 & 91,04 \\
\hline $\begin{array}{l}\text { Wojskowy Instytut Medyczny } \\
\text { w Warszawie }\end{array}$ & Mazowieckie & 0,3 & $0,38 \%$ & $99,64 \%$ & $91,70 \%$ \\
\hline $\begin{array}{l}\text { Warsaw Medical Center - } \\
\text { Warszawskie Centrum Medyczne } \\
\text { Sp. z o.o. }\end{array}$ & Mazowieckie & 0,3 & $0,00 \%$ & $100,00 \%$ & $100,00 \%$ \\
\hline $\begin{array}{l}\text { SPZOZ Uniwersytecki Szpital Kliniczny } \\
\text { Nr } 1 \text { im. N.Barlickiego UM w Łodzi }\end{array}$ & tódzkie & 0,2 & $0,41 \%$ & $99,59 \%$ & $85,77 \%$ \\
\hline $\begin{array}{l}\text { Mazowiecki Szpital Wojewódzki } \\
\text { w Siedlcach Sp. z o.o. }\end{array}$ & Mazowieckie & 0,2 & $3,03 \%$ & $96,97 \%$ & $90,91 \%$ \\
\hline $\begin{array}{l}\text { Szpital Uniwersytecki Nr } 1 \text { im. } \\
\text { dr. A. Jurasza w Bydgoszczy }\end{array}$ & $\begin{array}{l}\text { Kujawsko- } \\
\text { pomorskie }\end{array}$ & 0,2 & $0,88 \%$ & $99,12 \%$ & $93,86 \%$ \\
\hline $\begin{array}{l}\text { Uniwersytecki Szpital Kliniczny } \\
\text { im. J. Mikulicza-Radeckiego } \\
\text { we Wrocławiu }\end{array}$ & Dolnośląskie & 0,2 & $2,66 \%$ & $97,35 \%$ & $89,38 \%$ \\
\hline $\begin{array}{l}\text { Mazowiecki Szpital Bródnowski } \\
\text { w Warszawie Sp. z o.o. }\end{array}$ & Mazowieckie & 0,2 & $2,35 \%$ & $97,65 \%$ & $96,71 \%$ \\
\hline SPZOZ MSWiA w Lublinie & Lubelskie & 0,2 & $0,00 \%$ & $100,00 \%$ & $85,50 \%$ \\
\hline
\end{tabular}

\section{Dyskusja}

Przewlekłe zapalenie zatok przynosowych stanowi istotny populacyjny problem zdrowotny. Według dostępnych w piśmiennictwie danych epidemiologicznych występowanie PZZP w Europie szacuje się na około 11\% populacji [9]. W USA w 1997 roku odnotowano, że prawie 15\% mieszkańców leczy się z tego powodu, jednocześnie jest to najczęstsza choroba przewlekła, która dotyczy $37 \mathrm{mln}$ obywateli USA [11]. Natomiast w Polsce, zgodnie z danymi zamieszczonymi w opracowaniu MPZ, problem chorób nosa i zatok przynosowych dotyka około $12 \%$ populacji. Ocenia się, że jeśli chodzi o zapadalność, jest to druga najczęstsza jednostka chorobowa po zezie i niedowidzeniu.
Pod względem chorobowości zajmuje piąte miejsce po zezie i niedowidzeniu, chorobach kręgosłupa, zaburzeniach miesiączkowania oraz chorobach stawów. Choroby nosa i zatok przynosowych są jednocześnie najczęściej występującym schorzeniem wśród chorób z zakresu otorynolaryngologii oraz drugą przyczyną hospitalizacji w tej grupie po chorobach jamy ustnej i gardła.

Przewlekłe zapalenie zatok dotyczy przede wszystkim młodych dorosłych, czynnych zawodowo. Ze względu na chroniczny przebieg choroba ta jest przyczyną niezdolności do pracy, pacjent wymaga długoterminowej opieki, przewlekłego przyjmowania leków, częstych wizyt ambulatoryjnych, hospitalizacji, często z leczeniem 
Tabela 5. Dominujące procedury w grupach wiekowych.

Table 5. Dominant procedures in age groups.

\begin{tabular}{|c|c|c|c|c|}
\hline \multirow{2}{*}{ Procedura ICD-9 } & \multicolumn{3}{|c|}{ Grupa wiekowa } & \multirow{2}{*}{ Suma PL } \\
\hline & $18-44$ & $45-69$ & $70+$ & \\
\hline 22.53 Otwarcie wielu zatok nosa & 3643 & 3826 & 462 & 7931 \\
\hline 21.841 Plastyka przegrody nosowej & 1048 & 781 & 48 & 1877 \\
\hline 22.58 Endoskopowe otwarcie wielu zatok nosa & 842 & 914 & 99 & 1855 \\
\hline 22.51 Otwarcie komórek sitowych & 391 & 571 & 92 & 1054 \\
\hline 22.63 Wycięcie komórek sitowych & 441 & 490 & 43 & 974 \\
\hline 21.311 Wycięcie polipa nosa & 290 & 578 & 104 & 972 \\
\hline 21.61 Wycięcie małżowiny nosa (diatermia/ krioterapia/laserochirurgia) & 498 & 363 & 29 & 890 \\
\hline 22.61 Wycięcie zmiany zatoki szczękowej z dostępu Caldwella-Luc’a & 481 & 341 & 47 & 869 \\
\hline 22.391 Otwarcie zatoki szczękowej z dostępu Caldwella-Luc’a & 363 & 331 & 40 & 734 \\
\hline 22.2 Antrotomia przeznosowa & 292 & 296 & 29 & 617 \\
\hline 22.311 Usunięcie wyściółki zatoki drogą zabiegu Caldwella-Luc’a & 204 & 187 & 34 & 425 \\
\hline 21.69 Wycięcie małżowiny nosa - inne & 151 & 128 & 14 & 293 \\
\hline 22.01 Punkcja zatoki nosa/ płukanie/aspiracja & 101 & 120 & 26 & 247 \\
\hline 21.01 Przednia tamponada nosa przy krwotoku & 101 & 125 & 19 & 245 \\
\hline 22.52 Otwarcie zatoki klinowej & 70 & 102 & 19 & 191 \\
\hline 22.00 Aspiracja/płukanie zatok nosa - inne & 91 & 84 & 12 & 187 \\
\hline 22.71 Zamknięcie przetoki zatoki nosa & 96 & 60 & 10 & 166 \\
\hline 22.41 Otwarcie zatoki czołowej & 52 & 76 & 9 & 137 \\
\hline 22.62 Wycięcie zmiany zatoki szczękowej - z innego dostępu & 75 & 48 & 5 & 128 \\
\hline $\begin{array}{l}23.1704 \text { Usunięcie zęba przez dłutowanie zewnątrzzębodołowe z wytworzeniem } \\
\text { płata śluzówkowo-okostnowego }\end{array}$ & 67 & 46 & 7 & 120 \\
\hline 22.31 Radykalna antrotomia (otwarcie) zatoki szczękowej & 44 & 50 & 7 & 101 \\
\hline
\end{tabular}

chirurgicznym. Niejednokrotnie dolegliwości utrzymują się pomimo wdrożenia prawidłowego leczenia. Wiąże się to $\mathrm{z}$ obniżeniem jakości życia wśród pacjentów.

Z powodu chorób nosa i zatok przynosowych najczęstszą przyczyną hospitalizacji było rozpoznanie J32.8 - „Inne przewlekłe zapalenie zatok". Pacjenci byli hospitalizowani na oddziałach otorynolaryngologicznych, otolaryngologicznych leczenia jednego dnia i otorynolaryngologicznych dla dzieci. Dominującą procedurą zabiegową ICD-9 sprawozdawana do NFZ było 22.53 - „Otwarcie wielu zatok nosa”, która nie wskazuje na metodę przeprowadzenia operacji oraz nie określa jednoznacznie zakresu przeprowadzonego zabiegu. Brak jest również mechanizmu weryfikacji zakodowanej procedury. Jednocześnie procedura ICD-9 22.53 była najczęściej wykonywaną we wszystkich grupach wiekowych. Często wykorzystywano ją do zakodowania np. operacji obustronnej zatok szczękowych. Zwraca uwagę różnica między poszczególnymi województwami w liczbie wykonywanych zabiegów. Istnieją województwa, w których część procedur nie była wykonywana.

MPZ zostały opracowane na podstawie danych sprawozdawanych przez świadczeniodawców do Narodowego Funduszu Zdrowia. Analiza uwzględnia tylko te jednostki, które miały podpisany kontrakt z NFZ w 2014 roku. Jej jakość i rzetelność uzależniona jest od jakości przekazanych do NFZ informacji. Na podstawie uzyskanych danych nie można precyzyjnie określić, które jednostki chorobowe są najczęstszą przyczyna wykonywania zabiegów operacyjnych, możemy jedynie podać, jakie rozpoznanie według kodów ICD-9 i ICD-10 było podawane najczęściej.

\section{Wnioski}

MPZ są narzędziem wspomagającym podejmowanie decyzji o charakterze systemowym, jak i działań prowadzonych w odniesieniu do poszczególnych uczestników systemu ochrony zdrowia. MPZ prezentują dane, analizy i wskaźniki, które mają umożliwić formułowanie wniosków i rekomendacji, natomiast nie zastępują procesu podejmowania decyzji. Projekt zakłada poprawę jakości zarządzania zasobami systemu ochrony zdrowia przy sporządzaniu planu zakupu świadczeń opieki zdrowotnej przez wojewódzkie oddziały Narodowego Funduszu Zdrowia.

Przewlekłe zapalenie zatok przynosowych jako schorzenie stanowi wyzwanie dla systemu ochrony zdrowia. Z populacyjnego punktu widzenia bardzo istotne jest wczesne podjęcie leczenia, co może się wiązać z jego lepszymi wynikami, jak również ze zmniejszeniem absencji w pracy z powodu występowania choroby przewlekłej. Nierównomierne rozmieszczenie wysokospecjalistycznych ośrodków powoduje nierówny dostęp pacjentów do opieki 
medycznej. Tym samym są oni narażeni na koszty związane $\mathrm{z}$ dojazdem do placówki medycznej oraz powstają różnice pomiędzy ośrodkami w czasie oczekiwania na leczenie. Ponadto skupianie się pacjentów wokół ośrodków wysokospecjalistycznych powoduje znaczne wydłużenie czasu oczekiwania na wizytę kontrolą w poradniach przyszpitalnych, co może uniemożliwiać regularne kontrole pacjentów chorych przewlekle. Wydaje się, że do ośrodków wysokospecjalistycznych powinni trafiać pacjenci w zaawansowanym stadium choroby, którzy wymagają doświadczonego zespołu w zakresie prawidłowej diagnostyki oraz leczenia. Natomiast chorzy wymagający rutynowych kontroli powinni być leczeni w poradniach rejonowych.

Obecnie nie istnieją jasne wytyczne dotyczące sposobu kodowania rozpoznań i procedur. Utrudnia to dokładną analizę porównawczą pomiędzy poszczególnymi województwami i podmiotami realizującymi procedury medyczne.

\section{Piśmiennictwo:}

1. Fokkens WJ, Lund VJ, Mullol J, Bachert C, Alobid I, Baroody F i wsp. EPOS 2012: European position paper on rhinosinusitis and nasal polyps 2012. A summary for otorhinolaryngologists. Rhinology, 2012; 50(1): 1-12.

2. Stevens WW, Schleimer RP, Kern RC. Chronic rhinosinusitis with nasal polyps. J Allergy Clin Immunol Pract, 2016; 4(4): $565-72$.

3. Kucuksezer UC, Ozdemir C, Akdis M, Akdis CA. Chronic rhinosinusitis: pathogenesis, therapy options, and more. Expert Opin Pharmacother, 2018: 19(16): 1805-15.

4. Thompson CF, Price CPE, He Huang J, Min JY, Suh LA, Shintani-Smith $\mathrm{S}$ i wsp. A pilot study of symptom profiles from a polyp versus an eosinophilic-based classification of chronic rhinosinusitis. Int Forum Allergy Rhinol, 2016; 6(5): 500-07.

5. Bardy JJ, Sarovich DS, Price EP, Steinig E, Tong S, Drilling A i wsp. Staphylococcus aureus from patients with chronic rhinosinusitis show minimal genetic association between polyp and non-polyp phenotypes. BMC Ear Nose Throat Disord, 2018; 18: 16.

6. Brook I. The role of antibiotics in pediatric chronic rhinosinusitis. Laryngoscope Investig Otolaryngol, 2017; 2(3): 104-08.

7. Juan F, Ayiheng Q, Yuqin F, Hua Z, Jun Y, Bin H. Risk factors of chronic rhinosinusitis after functional endoscopic sinus surgery. Med Sci Monit, 2017; 23: 1064-68.

8. Lourijsen ES, Borgie CAJM de, Vleming M, Fokkens WJ. Endoscopic sinus surgery in adult patients with chronic rhinosinusitis with nasal polyps (PolypESS): study protocol for a randomised controlled trial. Trials, 2017; 18: 39.

9. Beswick DM, Mace JC, Rudmik L, Soler ZM, Alt JA, Smith KA i wsp. Socioeconomic factors impact quality of life outcomes and olfactory measures in chronic rhinosinusitis. Int Forum Allergy Rhinol, 2018; doi: 10.1002/alr.22256.

10. McCoul ED. The condemned sinus: natural disease or surgical sequela? Ochsner J, 2018; 18(2): 141-45.
11. Kelly EA, Gollapudy S, Riess ML, Woehlck HJ, Loehrl TA, Poetker DM. Quality of surgical field during endoscopic sinus surgery: a systematic literature review of the effect of total intravenous compared to inhalational anesthesia. Int Forum Allergy Rhinol, 2013; 3(6): 474-81.

12. Ministerstwo Zdrowia. Mapy potrzeb zdrowotnych. http://www. mapypotrzebzdrowotnych.mz.gov.pl/ [dostęp: 15.05.2019].

13. Lethbridge-Cejku M, Schiller JS, Bernadel L. Summary health statistics for U.S. adults: National Health Interview Survey, 2002. Vital Health Stat, 2004; 10(222): 1-23.

14. Benjamin MR, Stevens WW, Li N, Bose S, Grammer LC, Kern $\mathrm{RC}$, et al. Clinical characteristics of patients with chronic rhinosinusitis without nasal polyps in an academic setting. J Allergy Clin Immunol Pract, 2018; S2213-2198(18)30671-8.

15. Cho SH, Kim DW, Gevaert P. Chronic rhinosinusitis without nasal polyps. J Allergy Clin Immunol Pract, 2016; 4(4): 575-82.

16. Kennedy DW, Shaman P, Han W, Selman H, Deems DA, Lanza DC. Complications of ethmoidectomy: a survey of fellows of the American Academy of Otolaryngology-Head and Neck Surgery. Otolaryngol Head Neck Surg, 1994; 111: 589-99.

17. Cumberworth VL, Sudderick RM, Mackay IS. Major complications of functional endoscopic sinus surgery. Clin Otolaryngol Allied Sci, 1994; 19: 248-53.

18. Krings JG, Kallogjeri D, Wineland A, Nepple KG, Piccirillo JF, Getz AE. Complications of primary and revision functional endoscopic sinus surgery for chronic rhinosinusitis. Laryngoscope, 2014; 124(4): 838-45. 